\title{
Publicidade on-line: comunicação interativa
}

\section{Lucilene dos Santos Gonzales}

\begin{abstract}
Profa. Dra. Do Departamento de Ciências Humanas da Faculdade de Arquitetura, Artes e Comunicação da Unesp de Bauru. Orientadora da iniciação científica Convergência Midiática e Internet: uma proposta de ampliação da estratégia de comunicação da Agência Propagação e das propagandas do Minuto Consciente, realizada por Daniele Ferreira Seridório. Financiamento Fapesp 2012/13.lucilenegonzales@ uol.com.br.
\end{abstract}

Daniele Ferreira Seridório

\section{Resumo}

\begin{abstract}
Graduada em Jornalismo, FAAC, Unesp de Bauru, 2013. Mestranda do programa de pós-graduação stricto sensu Comunicação Midiática, da Faculdade de Arquitetura, Artes e Comunicação da Unesp de Bauru. Orientanda da iniciação científica Convergência Midiática e Internet: uma proposta de ampliação da estratégia de comunicação da Agência Propagação e das propagandas do Minuto Consciente. Financiamento Fapesp 2012/13. daniseridorio@gmail.com
\end{abstract}

A publicidade na era digital reconfigurou-se; seus tradicionais paradigmas estão obsoletos, principalmente no que diz respeito à interação com seu público-alvo. Antes considerada uma comunicação em um só sentido, em que o fabricante e o anunciante se dirigem a um público que não podiam responder à comunicação emitida, agora o consumidor tem voz opina sobre a marca e é também co-produtor de marcas e produtos. As plataformas e estratégias dessa publicidade online interativa são objeto de reflexão deste artigo.

Palavras-chave: Publicidade online, Interatividade, Marketing digital.

\section{Abstract}

In digital era advertising had suffer a transformation, the traditional methods are now obsolete, especially when it comes to interaction with the target public. Before this, advertising was considered as a one way communication, where the brand talks to the public, who only received the message, with no power to respond to it. Now a days, with digital platform, the consumer have ways to interact with advertising by responding to messages and acting like co-producers. This way, the digital platforms and the strategies of online advertising are the objects of this article discussion.

Keywords: Online advertising; Interaction; Digital marketing.

\section{Resumen}

La publicidad sufrió una revolución en la era digital, sus métodos tradicionales están obsoletos ahora, especialmente en la interacción con el público. Antes, la publicidad era considerada una forma de comunicación en un solo sentido, en que la marca se dirigía al público, y el no podía responder al mensaje. Hoy día, con los medios digitales, el consumidor tiene voz y puede opinar sobre la marca y actuar como agente productor de marcas, productos y mensajes. Las plataformas y las estrategias de la publicidad online y interactiva son los objetos de la reflexión del ensayo.

Palabras clave: Publicidad online; Interactividad; Marketing digital.

\section{Introdução}

Nossa sociedade vive um novo fenômeno técnico, social, político, mercadológico: a cultura de convergência em que o potencial das novas mídias digitais e comunidades virtuais possibilitam formas de comunicação interativas e colaborativas.

Denominada cibercultura, esse cotidiano contemporâneo imerge o homem pós-moderno 
num ambiente online e digital, meio imaterial dominado por bits e códigos binários que começou a nascer, após a Segunda Guerra Mundial. Este novo sistema técnico - a energia nuclear, informática e engenharia genética- afetou o cotidiano de forma radical com a instauração da sociedade do consumo e do espetáculo.

Essa reestruturação social e cultural potencializou-se com o fenômeno da globalização, impulsionado em grande escala pela Internet, tecnologia que permitiu o desenvolvimento de novas formas digitais de comunicação midiáticas que passou a utilizar a web como uma plataforma de transmissão.

Nesse ambiente online contemporâneo, a circulação de informações não obedece ao esquema da difusão centralizada da informação massiva um-todos; a mídia digital permite a interação todos-todos. No universo da web, pessoas que não tinham acesso à produção de conteúdo agora podem consumi-lo e produzi-lo, afetando diretamente as marcas.

Engrenagem da cultura da sociedade, a publicidade agora também está online nesse novo paradigma comunicacional, explorando nos novos media a interatividade com o consumidor.

A primeira aparição da publicidade online interativa foi a publicação de banners na internet, imitando a mídia tradicional; nesta forma de publicidade, a interatividade resumia-se a um click do consumidor para ir à página do anunciante. Mas a interação do público com as marcas não parou por aí.

$\mathrm{Na}$ era das redes sociais, a publicidade online utiliza-se de estratégias de marketing digital como o marketing de conteúdo, mídias sociais - blogs, Facebook, Twitter, Youtube, Instagram-, interagindo em graus diferentes com seus consumidores para a gestão das marcas.

Trata-se do conhecimento compartilhado, um processo social que ocorre nas redes sociais, onde cada indivíduo contribui com um fragmento do conhecimento - inteligência coletiva-, expondo sua opinião e compartilhando sua experiência com outros internautas em escala digital e global.

Essas formas de comunicação interativa da publicidade online com seus públicos são objeto de estudo deste artigo que pretende descrever as plataformas e estratégias dessas mensagens mercadológico-interativas na cultura de convergência.

2. A reconfiguração da publicidade na era digital

A convergência cultural é um fenômeno contemporâneo em que ocorrem transformações culturais, sociais, tecnológicas e mercadológicas.

\begin{abstract}
Por convergência, refiro-me ao fluxo de conteúdos através de múltiplas plataformas de mídia, à cooperação entre múltiplos mercados midiáticos e ao comportamento migratório dos públicos dos meios de comunicação, que vão a quase qualquer parte em busca das experiências de entretenimento que desejam. Convergência é uma palavra que consegue definir transformações tecnológicas, mercadológicas, culturais e sociais, dependendo de quem está falando e do que imaginam estar falando (JENKINS, 2009, p. 29).
\end{abstract}

Diferente de contexto contemporâneo, Gonzales (2003, p. 14) definiu, na era analógica, o 
texto publicitário como uma comunicação em um só sentido, em que o "o fabricante e o anunciante se dirigem a um público que não pode responder à comunicação emitida; nesse sentido, o discurso publicitário é autoritário (Citelli, 1995, p.46), pois não há como o receptor do anúncio manifestar sua opinião sobre a mensagem recebida".

Existiam, nessa época, raras possibilidades de interatividade na publicidade. Em 1908, um anúncio da Casa Mangueira, com o desenho de um chapéu de um lado e de uma cabeça de um homem de outro, separados por uma linha vertical, convidava o leitor a aproximar seu nariz no centro do anúncio para ver o chapéu, produto propagado, se acomodar na cabeça do homem (CARRASCOZA, 1999, p. 166-8).

Aparecem também anúncios interativos a partir de 1990, utilizando aroma, 'facas especiais', em $3 \mathrm{D}$ ou apenas títulos que visam quebrar a leitura passiva do receptor, levando-o a ser ativo na decodificação da informação. Essa interatividade, alerta Carrascoza (1999), não era tão usada pelo custo elevado.

Podemos inferir também que a manifestação máxima do consumidor, na era analógica dos meios de comunicação de massa, era não atender ao pedido do anunciante e não comprar o produto ou serviço ou não acatar a ideia proposta na mensagem.

$\mathrm{O}$ advento da internet, porém, quebrou esse paradigma de quase total unilateralidade da comunicação publicitária e contemporaneamente a comunicação com o público-alvo da mensagem tornou-se uma comunicação de todos para todos, já que o fabricante/anunciante, agência e público dialogam, na mídia digital, e este último expõe sua opinião sobre a mensagem recebida, ou sobre produtos e serviços nas diversas plataformas digitais. Dizemos, então, que, na era digital, há interação em diversos níveis com a finalidade também de persuadir, seduzir esse consumidor, incitá-lo ao consumo e fortalecer a marca da organização.

\section{A publicidade digital na era da convergência midiática}

Contemporaneamente, vivemos o fenômeno da possibilidade total de interação e fluxo de comunicação dentro das mais variadas esferas comunicacionais; a sociedade tem a seu dispor a comunicação multidirecional, na qual o público é parte fundamentalmente integrante do fenômeno digital, o chamado multiprotagonismo da sociedade, agora colaborativa, participativa e com conteúdo descentralizado.

\footnotetext{
Por convergência, refiro-me ao fluxo de conteúdos através de múltiplas plataformas de mídia, à cooperação entre múltiplos mercados midiáticos e ao comportamento migratório dos públicos dos meios de comunicação, que vão a quase qualquer parte em busca das experiências de entretenimento que desejam. Convergência é uma palavra que consegue definir transformações tecnológicas, mercadológicas, culturais e sociais, dependendo de quem está falando e do que imaginam estar falando (JENKINS, 2009, p. 29).
}

Quando falamos em mídias na Internet, temos de levar em consideração que sua característica multimídia e que o formato e estrutura de cada site cria uma forma diferente de veiculação da mensagem. Antes da existência da banda larga não havia como utilizar de forma eficiente o vídeo e a animação com o Youtube que literalmente criaram uma nova mídia, permitindo a veiculação de vídeos na internet. Com o aumento da capacidade dos computadores surgiu o Java e o 
Flash, e com eles a possibilidade de criação de animação e jogos on-line, novamente criando uma nova mídia na Internet (TORRES, 2009, p. 242).

A interatividade, antes pouco explorada nas mídias tradicionais, na era digital é sua principal estratégia de comunicação.

\begin{abstract}
A internet é um meio e comunicação bidirecional, interativo. As pessoas sempre sentiram falta de se expressar na mídia, seja pela televisão, pela mídia impressa ou pelo rádio. Esses meios sempre significaram alguma forma de interação, mas em, em geral, com um volume e destaque muito inferior ao que se dá em uma matéria ou à publicidade. Assim, o consumidor podia enviar uma carta para o jornal ou ligar para a rádio, mas ficava em um canto chamado "palavra do leitor" ou algo assim (TORRES, 2009, p.36).
\end{abstract}

E a interatividade não é apenas um fenômeno técnico. Após o advento das mídias digitais, que modificou hábitos diários das pessoas, revolucionou a informação, estabeleceu parâmetros de comportamento e impôs profundas mudanças nos relacionamentos, principalmente após o surgimento das mídias sociais, verificamos que o marketing e a publicidade on-line reconfiguraram-se.

Agora a interação deve ser percebida como uma questão de base e não apenas como uma característica intrínseca que não exige reflexão. Há gradações de intensidade e variações qualitativas que se encontram nas interações em ambientes informáticos. Ainda existe a interação construída durante o processo de relação entre os interagentes, que vai além da interação reativa programada por antecedência (PRIMO, 1998).

Silva (2000, p. 11), no mesmo sentido, reflete sobre a interatividade na contemporaneidade:

Emerge como a instauração de uma nova configuração tecnológica (no sentido das tecnolo-
gias informáticas conversacionais), e de uma nova dimensão mercadológica (no sentido da
busca do diálogo entre produtor-produto-cliente). Mas isso ocorre imbricado em transfor-
mações que se dão na esfera social, onde se pode observar não mais a pregnância da passiv-
idade da recepção diante da emissão do produto acabado, mas uma crescente autonomia de
busca onde cada indivíduo faz por si mesmo, num ambiente polifônico, polissêmico que vem
à tona quando ocorre o enfraquecimento dos grandes referentes que determinavam signifi-
cações ou verdades acabadas para o consumo passivo das massas (SILVA, 200o, p. 11).

Esse autor reforça a ideia de criação conjunta, em que o receptor 'passivo' torna-se "co-autor, co-criador, verdadeiro conceptor", estando a noção de interatividade assentada nos binômios participação-intervenção, bidirecionalidade-hibridação e permutabilidade-potencialidade (SILVA, 2000, p. 12).

A internet tornou-se, dessa forma, um ambiente que afeta o marketing da empresa de diversas formas, seja na comunicação corporativa, seja na publicidade, e continuará afetando o marketing mesmo que a organização não invista um centavo nela. Ao contrário da mídia tradicional, em que o controle é dos grupos empresariais, na internet o controle é do consumidor. Assim, mesmo que a organização não participe dela, os consumidores estarão lá, falando sobre os produtos e serviços, comprando a empresa com as dos concorrentes, e, finalmente, buscando formas de se relacionar com sua marca (TORRES, 2009, p. 61). 


\section{Formas de publicidade online interativa}

Como a publicidade é uma ferramenta do marketing digital, focada na promoção/ comunicação de produtos, serviços e ideias, a Internet apresenta-se como uma mídia de infinitas possibilidades para a veiculação publicitária.

Nessa nova fase midiática, a internet vem dando novos moldes à publicidade que pode lançar mão de recursos tradicionais muitas vezes como a divulgação de panfletos em vias públicas, ou a poluição visual nas ruas. A internet viabiliza um acervo de publicidade em um clique, de uma forma mais simples e rentável, especialmente quando se refere aos banners como forma de publicidade online.

\footnotetext{
Os banners são, sem dúvida alguma, a forma mais simples e direta de publicidade na Internet. Podem ter diversos formatos e são apresentados em posições definidas no site. O conceito do banner é simples e similar ao do anúncio em revistas e jornais. O consumidor está acessando a página, vê o banner e recebe a mensagem publicitária. Em geral, um clique sobre o banner leva ao site do anunciante, mas existem banners que apresentam somente o endereço do anunciante (TORRES, 2009, p. 245).
}

A publicidade online, porém, expandiu-se para muito além dos tradicionais banners. Hoje as alternativas são inúmeras, e as tecnologias que podem ser empregadas também. O mais importante é entender que se trata de um modelo diferente de veiculação publicitária na televisão, no rádio, na mídia impressa ou na mídia exterior, e copiar peças dessas mídias para a publicidade on-line pode não ser a melhor alternativa (TORRES, 2009, p.78).

Segundo esse autor, para desenvolver estratégias de marketing e publicidade digital, deve-se levar em consideração o comportamento, a intenção, o desejo e as necessidades das pessoas usuárias da Internet que buscam essa mídia para interagir em quatro atividades básicas: relacionamento, informação, comunicação, diversão.

O grande uso pelos internautas de redes sociais como Facebook, Twitter, Instagram, Myspace fez com que os profissionais de marketing logo se apropriassem do uso desse terreno fértil digitalizado, incorporando-as para as organizações de forma mercadológica, rentável e viável. O uso dessas mídias permitiu e fez com que tablets, smartphones e notebooks deixassem as pessoas mais tempo conectadas, tendo assim uma maior vulnerabilidade diária para publicidade.

Com a publicidade na internet se tornando a nova mídia central no mundo atual, uma das vantagens é a facilidade de uma campanha alcançar um público extremamente segmentado, contando com a interatividade que o consumidor conquistou nessa era do marketing digital.

\footnotetext{
O uso do modelo (comunicação, informação, relacionamento e diversão) permite entender que o consumidor usa o Google principalmente para buscar informações e não para encontrar sites, portanto, dará mais atenção ao conteúdo do que a qualquer publicidade. Surge então a necessidade de se criar uma estratégia de marketing baseada em conteúdo (TORRES, 2009, p. 66).
}

Essa nova estratégia de comunicação mercadológica, o marketing de conteúdo 
é o uso do conteúdo em volume e qualidade suficientes para permitir que o consumidor encontre, goste e se relacione com uma marca, empresa ou produto [...] Trata-se de aproveitar a dinâmica já criada na Internet, entre consumidores e ferramentas de busca, e utilizar isso a seu favor. A ideia é gerar conteúdo genuíno, útil e relevante para o consumidor, isento de interferência comercial (TORRES, 200, p. 87).

Ações efetivas de marketing de conteúdo oferecem informações relacionadas ao produto ou marca e atingem o mesmo público-alvo. As mídias e redes sociais também auxiliam na divulgação e difusão do conteúdo que é produzido para a mídia tradicional e digital. O Facebook, por exemplo, é um grande aliado nas publicações no blog e no canal do You Tube, já que poucas pessoas acessam todas as suas redes sociais. Por isso, é preciso integrá-las com estratégias de divulgação constante, explorando o marketing de mídias sociais para veicular conteúdo.

O ponto mais importante na mídia social é a possibilidade de relacionamento, assim, a marca passa a fazer parte do dia-a-dia dos públicos e passa a entender melhor seus gostos e comportamento.
O marketing de relacionamento consiste em uma estratégia que visa construir ativamente relacionamentos duradouros entre a empresa e seus clientes, contribuindo para garantir resultados sustentáveis. O objetivo maior é manter o cliente por meio da confiança, credibilidade e sensação de segurança transmitidas pela empresa (TORRES, 2009, p. 117).

As redes sociais devem promover divulgação do conteúdo produzido em seu blog e site institucional, e estabelecer comunicação e relacionamento com o internauta consumidor.

Outra maneira de explorar a produção de conteúdo é pela criação de peças virais. O chamado marketing viral é a versão digital do antigo boca-a-boca.

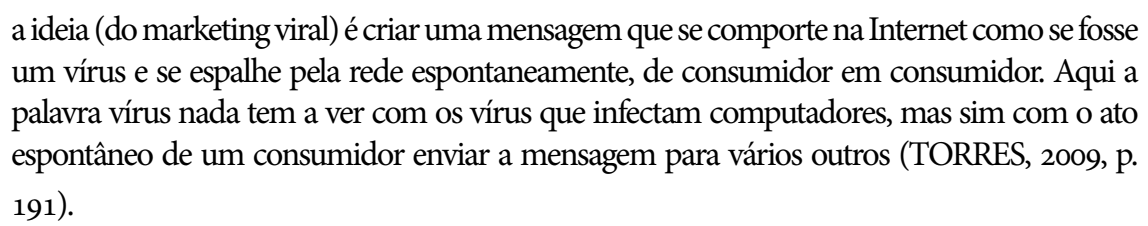

O formato mais comum de produção viral são os vídeos, mas imagens também são utilizadas com essa finalidade. Uma ação de marketing viral, como qualquer outra ação, deve ter público-alvo, objetivo e mensagem a ser passada.

\begin{abstract}
A peça viral é o elemento de transporte da sua mensagem. Pode ser um vídeo, um widget ${ }^{1}$, um jogo em Flash, uma música ou qualquer outro tipo de serviço ou produtos que você cria para ser distribuído livremente e propagar sua mensagem. A peça viral é o elemento visível do marketing viral, mas não é o único. É importante porque é o que dará o impulso e criará o interesse necessário para que siga em frente de mão em mão, de boca em boca [...] A rede de distribuição, ou qualquer propagação, é a rede social ou meio pelo qual a peça viral será transmitida. É o suporte físico da peça viral, e muitas vezes é também a rede pela qual os consumidores passarão a mensagem adiante (TORRES, 2009, p. 194).
\end{abstract}

A publicidade nas mídias sociais, assim como os conceitos de marketing nas mídias sociais, está ligada à produção de conteúdo colaborativo, publicação de vídeos, fotos e artes gráficas virais. No caso de redes sociais, como, por exemplo, o Facebook, as possibilidades são restritas, pois a rede 
é fechada e controlada por uma empresa. Para Torres (2009, p. 243), é mais adequado publicar com banners, aplicativos e widgets sociais.

O podcast também pode ser utilizado como publicidade online.

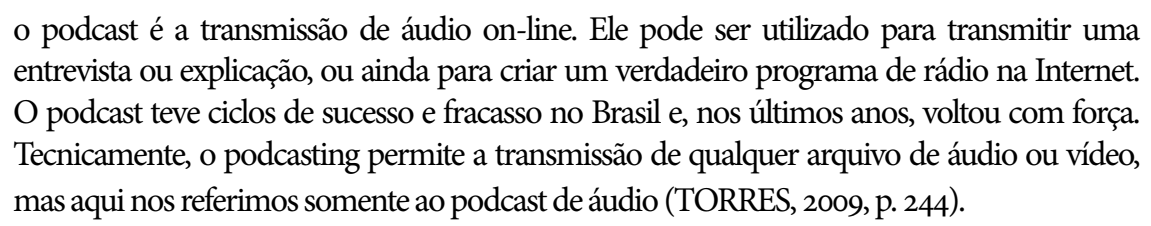

A Internet utilizada como meio de publicidade inova também a relação tradicional cliente-agência-mídia, já que agora a própria agência mantém a suas plataformas de mídia no meio digital. E o próprio cliente pode propor ações em hotsites e em suas páginas nas redes sociais e em seu site.

\begin{abstract}
A Internet quebrou o paradigma da relação cliente-agência-mídia. Tradicionalmente, o cliente contrata uma agência de publicidade, que elabora um planejamento de mídia que cria uma peça publicitária e veicula nos veículos de comunicação existentes. Assim, o cliente, a agência e a mídia são sempre três entidades diferentes (TORRES, 2009, p. 267).
\end{abstract}

A produção de conteúdo e abordagem das estratégias nas mídias sociais não surte efeito sem a devida divulgação, por isso o mailing entra como ferramenta para atingir um público que ainda não tem o costume de acessar a página em questão.

A pesquisa e o monitoramento entram como estratégias para conhecer o público-alvo e pensar em maneiras de melhorar a produção de conteúdo e o relacionamento com o internauta.

A estruturação de uma pesquisa online inicia-se pela formulação das perguntas que a pesquisa deve responder, depois as mídias e as fontes, por fim, é preciso definir as palavras-chave para implementar a pesquisa.

A pesquisa online também auxilia a determinar a relevância de conteúdo no ciberespaço. Utilizando as ferramentas de busca é possível obter resultados da colocação do site na pesquisa do Google, quantas citações em outros sites e quais palavras-chave estão relacionadas ao site da empresa e marca. A pesquisa de mídia online consiste em buscar na internet as mídias que se adaptam a seu público-alvo e classificá-las de acordo com sua importância, permitindo o uso do futuro da informação na tomada de decisão da veiculação de propaganda (TORRES, 2009, p. 226).

O monitoramento das ações e mídias digitais é, para Torres (2009), a ação central que regula uma atividade de marketing digital integrada. Ele também permite obter diversas informações referentes ao seu público-alvo, é justamente a configuração de códigos da Internet que possibilita o rastreamento e documentação destes dados.

\footnotetext{
Quando o usuário seleciona um site, seu navegador envia uma série de mensagens pela rede, primeiro localizando onde está o site e depois solicitando ao servidor onde o site é hospedado qual a página inicial. Para solicitar essa página, o navegador abre uma seção de comunicação com o servidor, e depois solicita os arquivos relacionados à pagina. Se a página contém figuras e outros elementos, o navegador vai solicitando cada um dos elementos até que a página esteja completa (TORRES, 2009, p. 275).
} 
Compreendendo essas etapas técnicas de navegação, é possível entender as estatísticas de monitoramento e relacioná-las a cada momento em que o usuário passou em determinado site.

\section{Considerações Finais}

Recentemente, Eric Schmidt, chairman executivo do Google, fez uma projeção de que "o mundo inteiro estará online até 2020 ". Tendenciosa ou não, tal proeminência afeta o cotidiano de todos, conectados ou não às redes atuais.

Mesmo na América Latina, marcada historicamente por desigualdades no acesso à informação e à internet, é possível destacar políticas públicas de inclusão neste sentido. No Brasil, por exemplo, foi instituído em maio de 2010, o Programa Nacional de Banda Larga, pelo decreto $\mathrm{n}^{\mathrm{a}}$ 7.1175/201, com o objetivo de fomentar e difundir o uso e o fornecimento de bens de serviços de conexão à Internet em banda larga, promovendo, portanto, a inclusão digital.

Em um meio à grande expansão da banda larga, a próxima tendência será a implementação de banda larga através de fibra e a implantação do $4 \mathrm{G}$, já que a sociedade está habituada com a sua participação nas novas mídias, interagindo com pessoas e marcas. A publicidade online consequentemente insere-se nessa dinâmica social, apresentado aos públicos produtos e serviços em diferentes plataformas digitais cuja maior modernidade é a possibilidade de interação entre marcas e consumidores.

Na sociedade contemporânea, essa revolução social, cultural, tecnológica, mercadológica, reconfigurou a comunicação midiática com seus públicos, incluindo a reformatação da publicidade, agora com novos paradigmas para atender às necessidades desse novo público da cibercultura, interativo e colaborativo.

$\mathrm{Na}$ era do relacionamento com os consumidores, a interatividade na Internet abriu possibilidades infinitas de as marcas informarem, se comunicarem e divertir seu público-alvo, estreitando relações com o consumidor para agregar valor às marcas.

O banner, primeira aparição da publicidade na era digital, permanece como estratégia de publicidade online; agora o marketing digital gera conteúdo nas novas plataformas digitais, em sites de busca, nas mídias sociais, Facebook, blogs, Twitter, Instagram, assim como o marketing viral e o podcast atraem os consumidores mais informados, exigentes e interativos.

A publicidade, com o advento da internet e consequente mudança de percepção e relação dos públicos - agora muito interativos - com as novas mídias, consequentemente inseriu-se nas novas plataformas de comunicação implementadas na web, convergindo suas estratégias digitais com os meios tradicionais da comunicação mercadológica.

Notas

1. O widget é um aplicativo interativo, que pode ser utilizado em diversas plataformas, por exemplo, em um site, no desktop de um computador, dependendo da maneira como foi programado. 
Referências bibliográficas

CARRASCOZA, J. A. A evolução do texto publicitário. São Paulo: Editora Futura, 1999.

CITELLI, A. O. Linguagem e persuasão. São Paulo: Ática, 2003.

GONZALES, L. Linguagem publicitária: análise e produção. São Paulo: Arte \& Ciência, 2003 .

JENKINS, H. Cultura da Convergência: Tradução Susana Alexandrina. 2 ed. São Paulo: Aleph, 2009.

KOTLER, P. Marketing de A a Z. 7 ed. Rio de Janeiro: Elsevier, 2003. lo: Ediouro, 2009. Marketing para o século XXI: como criar, conquistar e dominar mercados. São PauMarketing 3.0: as forças que estão definindo o novo marketing centrado no ser humano. São Paulo: Campus, 2010.

LEMOS, A. Cibercultura: tecnologia e vida na cultura contemporânea. Porto Alegre: Sulina, 2008.

LÉVY, Pierre. Cibercultura: Tradução de Carlos Irineu da Costa. 3 ed. São Paulo: Editora 24, 2010.

LIMA, V. Regulação das comunicações: história, poder e direitos. São Paulo: Palaus, 2011.

MACLUHAN, M. Os meios de comunicação como extensão do homem. São Paulo: Cultrix, 1974 .

MIDDLETON, Clarke. Marketing de turismo: teoria e prática. Rio de Janeiro: Campus, 2002.

MORIN, E. Cultura de massa no século XX - o espírito do tempo- neurose. 7 ed. Rio de Janeiro: Forense, 1987.

PINHO, J. B. Comunicação em Marketing: Princípios da Comunicação Mercadológica. Campinas: Papirus, 2001.

PRIMO, A. Interação mediada por computador. Porto Alegre: Editora Sulina. 2007.

A Interação mútua e interação reativa: uma proposta de estudo. In: XXI Congresso da Intercom, 1998, Recife. Anais do GT de Teoria da Comunicação. 1998. 
RECUERO, R. A conversação em rede: comunicação mediada pelo computador e redes sociais na internet. Porto Alegre: Sulina, 2012.

SANTOS, F. Movimento e interatividade na web. Publish, São Paulo, v. 8 n.55, p. 24-25, jul-ago. 2001.

SILVA, M. A Sala de aula interativa. Rio de Janeiro: Quartet, 2000.

TORRES, C. A Bíblia do Marketing Digital: tudo o que você queria saber sobre marketing e publicidade na internet e não tinha a quem perguntar. São Paulo: Novatec, 2009.

\section{Referências eletrônicas}

RECUERO, R. Redes Sociais na Internet: considerações Iniciais. Intercom, 2004. Disponível em: http://www.portcom.intercom.org.br/pdfs/121985795651418859729998795470196200751. pdf, Acessado em outubro de 2012. 